\title{
Effects of galacto-oligosaccharide and bacterial status on mucin distribution in mucosa and on large intestine fermentation in rats
}

\author{
BY J. C. MESLIN ${ }^{1}$, C. ANDRIEUX ${ }^{2}$, T. SAKATA ${ }^{3}$, P. BEAUMATIN ${ }^{1}$, \\ M. BENSAADA ${ }^{2}$, F. POPOT ${ }^{2}$, O. SZYLIT ${ }^{2}$ AND M. DURAND ${ }^{1}$ \\ ${ }^{1}$ Laboratoire de Nutrition et Sécurité Alimentaire and ${ }^{2}$ Laboratoire decologie et de Physiologie du \\ Système Digestif INRA, Centre de Recherches de Jouy, 78352 Jouy-en-Josas Cédex, France \\ ${ }^{3}$ Ishinomaki Senshu University, Minamizakai Shinmito 1, Ishinomaki 986, Japan
}

(Received 4 November 1991-Accepted 4 June 1992)

\begin{abstract}
The purpose of the present paper was to study the effects of a dietary undigestible carbohydrate and intestinal microflora on mucin distribution (neutral, acid, sulphonated), glycolytic activities: $\beta$-Dgalactosidase $(E C 3.2 .1 .23), N$-acetyl- $\beta$-D-galactosaminidase $(E C 3.2 .1 .43), N$-acetyl- $\beta$-D-glucosaminidase $(E C 3.2 .1 .30)$, $\alpha$-L-fucosidase $(E C 3.2 .1 .51)$ and bacterial metabolism (gas production, short-chain fatty acids (SCFA) and lactic acid caecal concentration) in germ-free (GF), conventional (CV) and heteroxenic (HE) rats (GF rats associated with a human flora). Rats were fed on either a control diet or a diet containing $40 \mathrm{~g}$ trans-galactosylated oligosaccharide (TOS)/kg. In GF rats fed on the control diet caecal pH was almost neutral and glycolytic activities negligible. The number of mucuscontaining cells increased from the caecum to the colon for the three types of mucin. TOS had no effect in the caecum but it modified mucin cell repartition in the colon. In $\mathrm{CV}$ and $\mathrm{HE}$ rats fed on the control diet caecal pH was similar $(6.8)$, but caecal SCFA and lactic acid concentrations $(\mu \mathrm{mol} / \mathrm{g})$ and gas production $(\mathrm{ml} / 24 \mathrm{~h})$ were higher in $\mathrm{CV}(70,5 \cdot 9$ and $2 \cdot 3$ respectively) than in $\mathrm{HE}$ rats $(32,4.6$ and 0.4 respectively). In $\mathrm{CV}$, as in $\mathrm{HE}$ rats, acid-mucin-containing cells increased from the caecum to the colon and glycolytic activities were similar. TOS reduced acid-mucin-containing cells in the caecum of $\mathrm{CV}$ rats by twofold but had no effect in either the caecum or the colon of HE rats. TOS strongly increased $\beta$ galactosidase activity and slightly modified the other glycolytic activities. Its effect on bacterial metabolites depended on bacterial status. However, comparison between $\mathrm{CV}$ and $\mathrm{HE}$ rats showed no evident relationship between the number of mucus-containing cells and measured bacterial metabolites. Differences between CV and HE rats might be due to bacterial microflora specificity. TOS had an intrinsic effect on mucus cell distribution in the colon of GF rats. In CV and HE rats the presence of the flora abolished this effect.
\end{abstract}

Bacteria: Hindgut: Mucins: Oligosaccharide

Dietary fibres have complex effects on intestinal mucosa modifications (Cassidy et al. 1981); they induce activities of glycolytic enzymes which could participate in mucin degradation (Salyers et al. 1977; Hoskins \& Boulding, 1981).

Wheat bran and, to a lesser extent, cellulose increase labelled sulphate and $\left[{ }^{3} \mathrm{H}\right] \mathrm{glucose}$ incorporation into intestinal glycoproteins and mucins in rats (Schneeman et al. 1982; Vahouny et al. 1985).

Bran, pectin or gum increase acid mucin in the colon of pigs with less of neutral mucin (Moré et al. 1987).

The effects of natural fibres may be attributed either to their mechanical properties or to the endproducts of their fermentation by bacteria, i.e. the short-chain fatty acids (SCFA).

Bacterial flora alters mucin secretion; for example, compared with germ-free (GF) animals conventional (CV) animals exhibit fewer goblet cells in the large intestine of 
guinea-pigs (Sprinz et al. 1961) and piglets (Staley et al. 1970), mid small intestine and colon of piglets (Heneghan et al. 1979) and small intestine of dogs (Heneghan, 1979). GF rats and mice accumulate more mucus in their caecal contents (Loesche, 1968; Combe et al. 1976). However, conventionalization of GF rats results in hyperplasia of the crypt epithelial cells, including mucus-producing cells in the ileum and caecum (Ishikawa et al. 1986, 1989).

A trans-galactosylated oligosaccharide (TOS) is actually used in Japan in human food as a bifidobacterial factor (Ito et al. 1990). In humans TOS seems to be poorly digested by endogenous enzymes and is fermented by intestinal flora, as shown by breath test studies (Tanaka et al. 1983).

The purpose of the present paper was to study the effects of TOS on mucin (neutral, acidic, and sulphonated) distribution in the mucosa, bacterial glycolytic activities and bacterial fermentations. In order to dissociate the effects of TOS itself from those of different types of flora, GF and CV rats and rats born GF and inoculated with a human flora (heteroxenic (HE) rats) were compared, since the origin of the bacterial flora may lead to different fermentation products.

\section{MATERIALS AND METHODS}

Animals

Male GF, CV and HE inbred F344 rats ( 3 months old) were used. HE rats were obtained by inoculation of GF rats with human faecal flora. Human faeces provided by a methanoproducer were diluted $1: 20(\mathrm{w} / \mathrm{v})$ with $\mathrm{NaCl}(9 \mathrm{~g} / \mathrm{l})$ in an anaerobic chamber; $1 \mathrm{ml}$ of this dilution was inoculated orally twice during $24 \mathrm{~h}$. Temperature and relative humidity of the animal room were controlled $\left(21 \pm 2^{\circ}, 60 \pm 5 \%\right.$ respectively). The lighting schedule was also controlled ( $12 \mathrm{~h}$ light-12 h dark). Rats were placed in wire-mesh cages and GF and HE rats were kept in isolators (La Calhene, France) as already described (Le Coz et al. 1989).

\section{Diets}

Two diets were used; a control diet containing $(\mathrm{g} / \mathrm{kg}$ ) maize starch 660 , maize oil 40 , fish meal 230 , kaolin 50 , minerals and vitamins mixture (compositions previously described by Andrieux \& Sacquet (1986)) 20, and an experimental diet in which $40 \mathrm{~g}$ maize $\mathrm{starch} / \mathrm{kg}$ was replaced by $40 \mathrm{~g}$ TOS $/ \mathrm{kg}$. Sterilized feed (gamma irradiation, $40 \mathrm{kGy}$ in vacuum-sealed plastic bags) and water were given ad lib. to the rats.

\section{Experimental design}

Groups of four GF, CV and HE rats were fed for 1 month on the control or experimental diets. At the end of this adaptation period the $\mathrm{H}_{2}$ and $\mathrm{CH}_{4}$ produced were collected in a respiratory chamber (Le Coz et al. 1989). Then rats were killed by an overdose of sodium pentobarbitone (SANOFI, Aulnay/Bois, France; $60 \mathrm{mg} / \mathrm{kg}$ intraperitoneally). Caecal pH was measured. Intestinal segments with contents were taken from the caecum, proximal colon (20 $\mathrm{mm}$ aboral to the caecum) and distal colon $(20 \mathrm{~mm}$ oral to the rectum), frozen in isopentane cooled with liquid $\mathrm{N}_{2}$ and stored at $-80^{\circ}$ until required for sectioning.

The remaining caecal contents were frozen in liquid $\mathrm{N}_{2}$ and maintained at $-20^{\circ}$ until required for determination of SCFA, D- and L-lactic acids and bacterial glycolytic activities.

\section{Histological techniques}

Sections ( $10 \mu \mathrm{m}$ thick) were cut at $-20^{\circ}$ with a cryostat (Reichert-Jung Frigocut 2700$)$ and fixed with formaldehyde vapour at $40^{\circ}$ overnight. Sections were stained with periodic acid-Schiff reaction (PAS) for neutral mucin (McManus, 1946), alcian blue $8 \mathrm{GX}$ at pH 2.5 
(AB 2.5) for acid mucin (Mowry \& Winkler, 1956) and by high-Fe-diamine reaction without previous oxidation (HID) for sulphomucins (Spicer, 1965) and with a slight modification in the staining solution $\left(400 \mathrm{~g} \mathrm{FeCl}_{3} / 1\right.$ instead of $\left.100 \mathrm{~g} \mathrm{FeCl}_{3} / 1\right)$.

For each stain, histological slides were number-coded and examined for quantification by two observers unaware of the origin of the slides.

\section{Measurements of mucus-containing cells}

In the caecum, proximal and distal colon, on sections perpendicular to the mucosa, the number of mucus-containing cells in the crypt, cut from the base to the neck, was counted for twenty crypts on each specimen. The stain was taken up by the luminal mucus layer adherent to the epithelial cells and by the intraluminal mucus dispersed in the contents of the caecum only in CV and GF rats, and the extent of staining was expressed on a relative scale $( \pm$, null or faint; + , weak; ++ , moderate; +++ , intense).

\section{Analytical procedure}

$\mathrm{H}_{2}$ and $\mathrm{CH}_{4}$ were measured using a Quintron apparatus (model DP; Quintron-Instrument Co, Milwaukee, USA), SCFA by GLC (Szylit et al. 1988). D- and L-lactic acids were determined enzymically (UV Boehringer method; Meylan, France). Glycosidase activities were measured by the rate of release of $p$-nitrophenol from their $p$-nitrophenylglycoside. The reaction mixture contained $0.3 \mathrm{ml}$ substrate solution $(0.5 \mathrm{~mm})$ and $0.2 \mathrm{ml}$ caecal contents in phosphate buffer $(0.1 \mathrm{M})$ at the $\mathrm{pH}$ of the caecum. Incubation was performed at $37^{\circ}$ for 5,10 , and $30 \mathrm{~min}$ and $p$-nitrophenol concentration was measured as the absorbance at $400 \mathrm{~nm}$ after adding $2.5 \mathrm{ml} \mathrm{0.25} \mathrm{M}-\mathrm{Na}_{2} \mathrm{CO}_{3}$. Activities were expressed as $\mathrm{U} / \mathrm{g}$ wet caecal content. One unit was equivalent to $1 \mu \mathrm{mol} p$-nitrophenol released $/ \mathrm{min}$.

\section{Statistical analysis}

The results are expressed as means with their standard errors. Experimental values were compared by two-way analysis of variance with subsequent Fisher PLSD, Scheffé $F$ and Dunnett $T$ tests and with the Newman-Keuls multiple-range test (STATITCF software; ITCF, Paris, France).

\section{RESULTS}

Mucus-containing cells in caecum, proximal and distal colon

The caecal mucosa (Table 1) of GF rats fed on the control diet exhibited less mucuscontaining cells than that of $\mathrm{CV}$ rats irrespective of the mucin type studied. In GF rats, as in CV rats, the number of $\mathrm{AB} 2 \cdot 5$-positive cells was lower than that of PAS- and HIDpositive cells; tenfold in GF and threefold-fourfold in CV rats. Compared with their CV counterparts, HE rats had similar numbers of PAS- and HID-positive cells and significantly more AB 2:5-positive cells.

TOS had no effect in GF rats and very slight effects in CV and HE rats; there were fewer $\mathrm{AB} 2 \cdot 5$-positive cells in $\mathrm{CV}$ and more HID-positive cells in $\mathrm{HE}$ rats.

There was a greater extent of staining with AB 2.5 of the subepithelial lumen mucus layer in close contact to the epithelium in GF rats fed both with or without TOS in the diet when compared with $\mathrm{CV}$ rats (Table 2). Secreted mucus, assessed by the extent of staining, was more abundant in the intraluminal caecal contents than in the subepithelial lumen mucus layer, both for GF and CV rats, despite slight differences between mucin types.

In the proximal and the distal colon differences between GF and HE rats were small (Table 3). In the proximal colon of GF rats fed on the control diet the number of PASpositive cells was higher than that in $\mathrm{CV}$ rats, and $\mathrm{HE}$ rats had more PAS-positive and less $\mathrm{AB} 2 \cdot 5$-positive cells than $\mathrm{CV}$ rats. 
Table 1. Number of mucus-containing cells per crypt section in the caecum of germ-free $(G F)$, conventional $(\mathrm{CV})$ and heteroxenic $(H E)$ rats fed on control (C) or trans-galactooligosaccharide (TOS) diet*

(Mean values for four rats with their pooled standard errors; error df 18)

\begin{tabular}{|c|c|c|c|c|c|c|c|c|c|c|}
\hline Rats... & \multicolumn{2}{|c|}{ GF } & \multicolumn{2}{|c|}{$\mathrm{CV}$} & \multicolumn{2}{|c|}{$\mathrm{HE}$} & \multirow[b]{2}{*}{$\begin{array}{c}\text { Pooled } \\
\text { SEM }\end{array}$} & \multicolumn{3}{|c|}{ Variance analysis } \\
\hline Diet... & $\mathrm{C}$ & TOS & $\mathrm{C}$ & TOS & $\mathrm{C}$ & TOS & & Flora & Diet & $\begin{array}{l}\text { Inter- } \\
\text { action }\end{array}$ \\
\hline \multicolumn{11}{|l|}{ Mucin type } \\
\hline Neutral (PAS +) & $10^{\mathrm{b}}$ & $9^{\mathrm{h}}$ & $20^{\mathrm{a}}$ & $18^{\mathrm{a}}$ & $21^{a}$ & $22^{\mathrm{a}}$ & $0 \cdot 39$ & 0.001 & NS & NS \\
\hline Acid $(\mathrm{AB} 2 \cdot 5+)$ & $1^{d}$ & $1^{\mathrm{d}}$ & $5^{b}$ & $2 \cdot 5^{\circ}$ & $8 \cdot 2^{\mathrm{u}}$ & $8 \cdot 5^{\mathrm{a}}$ & 0.20 & $0 \cdot 001$ & 0.05 & 0.05 \\
\hline Sulpho (HID +) & $9^{d}$ & $10^{\mathrm{d}}$ & $16^{\mathrm{e}}$ & $14^{\circ}$ & $17 \cdot 7^{\mathrm{bc}}$ & $19 \cdot 8^{a}$ & $0 \cdot 33$ & $0 \cdot 001$ & NS & NS \\
\hline
\end{tabular}

a, b,e,d Mean values within the same horizontal line with unlike superscript letters were significantly different (Newman-Keuls test): $P<0 \cdot 05$.

PAS, periodic acid-Schiff; AB 2.5, Alcian blue pH 2.5; HID, high-Fe-diamine; +, positive response to stain; NS, not significant.

* For details of animals and diets, see p. 904.

Table 2. Extent of staining* of subepithelial luminal mucus layer and intraluminal mucus contents in the caecum of germ-free $(G F)$ and conventional $(C V)$ rats fed on control $(C)$ or trans-galacto-oligosaccharide (TOS) diet $\dagger$

(Mean values for four rats with their pooled standard errors)

\begin{tabular}{|c|c|c|c|c|c|}
\hline & \multirow{2}{*}{$\begin{array}{l}\text { Rats... } \\
\text { Diet... }\end{array}$} & \multicolumn{2}{|c|}{ GF } & \multicolumn{2}{|c|}{$\mathrm{CV}$} \\
\hline & & $\mathrm{C}$ & TOS & $\mathrm{C}$ & TOS \\
\hline \multicolumn{6}{|c|}{$\begin{array}{l}\text { Subepithelial luminal mucus layer } \\
\text { Mucin type }\end{array}$} \\
\hline Neutral (PAS +) & & + & ++ & + & ++ \\
\hline Acid $(A B 2 \cdot 5+)$ & & ++ & ++ & + & + \\
\hline Sulpho (HID +) & & ++ & ++ & ++ & $+1-$ \\
\hline \multicolumn{6}{|c|}{ Intraluminal mucus contents } \\
\hline Neutral (PAS +) & & ++ & ++ & ++ & $+t+$ \\
\hline Acid (AB 2.5+) & & +++ & $+t+$ & ++ & ++ \\
\hline Sulpho (HID+) & & ++ & ++ & ++ & +++ \\
\hline
\end{tabular}

PAS, periodic acid-Schiff; AB 2.5, Alcian blue pH 2.5; HID, high-Fe-diamine.

* Relative scale of intensity of staining; $+/-$, null or faint; + , weak; ++ , moderate; +++ , intense.

+ For details of animals and procedures, see pp. 904-905.

In the distal colon GF and HE rats had more PAS-positive cells and less AB 2.5- and HID-positive cells than CV rats.

With TOS in GF rats there were significantly less PAS, AB 2.5- and HID-positive cells in the proximal colon mucosa and more PAS-, AB 2.5- and HID-positive cells in the distal colon. $\mathrm{CV}$ rats had a significant increase in $\mathrm{AB} 2 \cdot 5$-positive cells, with no change in the other mucin-containing cells in the proximal colon and only a slight decrease of HIDpositive cells in the distal colon.

In HE rats slight variations occurred in PAS-, AB 2-5- and HID-positive cells with TOS; 


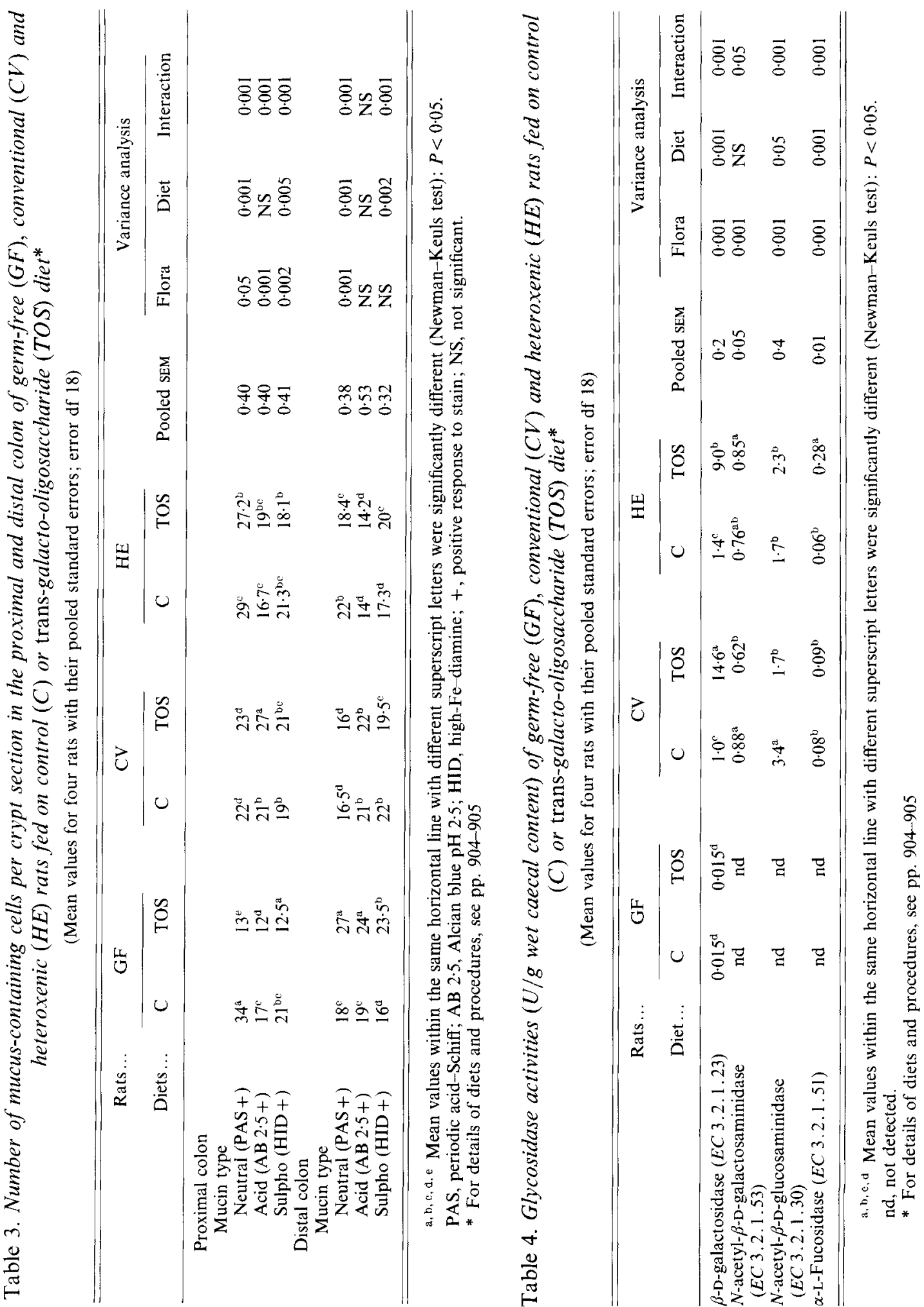


Table 5. Gas production $(\mathrm{ml} / 24 \mathrm{~h})$ of germ-free $(G F)$, conventional $(\mathrm{CV})$ and heteroxenic (HE) rats fed on control (C) or trans-galacto-oligosaccharide (TOS) diet*

(Mean values for four rats with their pooled standard errors; error df 18)

\begin{tabular}{|c|c|c|c|c|c|c|c|c|c|c|}
\hline \multirow{2}{*}{$\begin{array}{l}\text { Rats... } \\
\text { Diet... }\end{array}$} & \multicolumn{2}{|c|}{$\mathrm{GF}$} & \multicolumn{2}{|c|}{$\mathrm{CV}$} & \multicolumn{2}{|c|}{$\mathrm{HE}$} & \multirow[b]{2}{*}{$\begin{array}{l}\text { Pooled } \\
\text { SEM }\end{array}$} & \multicolumn{3}{|c|}{ Variance analysis } \\
\hline & $\mathrm{C}$ & TOS & $\mathrm{C}$ & TOS & $\mathrm{C}$ & TOS & & Flora & Diet & $\begin{array}{l}\text { Inter- } \\
\text { action }\end{array}$ \\
\hline $\begin{array}{l}\mathrm{H}_{2} \\
\mathrm{CH}_{4}\end{array}$ & $\begin{array}{l}\text { nd } \\
\text { nd }\end{array}$ & $\begin{array}{l}\text { nd } \\
\text { nd }\end{array}$ & $\begin{array}{l}0 \cdot 35^{\mathrm{b}} \\
2 \cdot 06^{\mathrm{b}}\end{array}$ & $\begin{array}{l}0 \cdot 76^{\mathrm{b}} \\
3 \cdot 41^{\mathrm{b}}\end{array}$ & $\begin{array}{l}0 \cdot 19^{\mathrm{b}} \\
0 \cdot 18^{\mathrm{c}}\end{array}$ & $\begin{array}{l}1 \cdot 63^{\mathrm{a}} \\
5 \cdot 02^{\mathrm{a}}\end{array}$ & $\begin{array}{l}0 \cdot 25 \\
0 \cdot 42\end{array}$ & $\begin{array}{l}0.01 \\
0.001\end{array}$ & $\begin{array}{l}0.01 \\
0.001\end{array}$ & $\begin{array}{l}0.05 \\
0.001\end{array}$ \\
\hline
\end{tabular}

$a, b, c$ Mean values within the same horizontal line with different superscript letters were significantly different (Newman-Keuls test) : $P<0.05$.

nd, not detected

* For details of diets and procedures, see pp. 904905.

a decrease in PAS-positive cells in the proximal colon, with a decrease in PAS-positive cells and an increase in HID-positive cells in the distal colon.

\section{Glycosidase activities in caecal content}

In GF rats a very low $\beta$-galactosidase (EC 3.2.1.23) activity was observed whatever the diet (Table 4). CV and HE rats fed on control diets exhibited only small differences in the $N$-acetyl- $\beta$-D-glucosaminidase (EC 3.2.1.30) activity which was lower in $\mathrm{HE}$ rats than in $\mathrm{CV}$ rats. The major effect of TOS intake in $\mathrm{CV}$ and $\mathrm{HE}$ rats was an increase in the $\beta$-galactosidase activity; however, this effect was more pronounced in CV rats. The other enzymes studied were only slightly modified: TOS lowered $N$-acetyl- $\beta$-D-galactosaminidase (EC 3.2.1.53) and $N$-acetyl- $\beta$-D-glucosaminidase in $C V$ rats and increased $\alpha$-L-fucosidase (EC 3.2.1.51) in HE rats.

\section{Gas production}

There was no $\mathrm{H}_{2}$ and $\mathrm{CH}_{4}$ production in GF rats (Table 5). With $\mathrm{CV}$ and $\mathrm{HE}$ rats fed on the control diet, $\mathrm{H}_{2}$ production was similar (about $0.2 \mathrm{ml} / 24 \mathrm{~h}$ ) but $\mathrm{CH}_{4}$ production differed greatly $(2 \mathrm{ml} / 24 \mathrm{~h}$ for CV rats $v .0 .18 \mathrm{ml} / 24 \mathrm{~h}$ for HE rats).

TOS intake increased significantly $\mathrm{H}_{2}$ and $\mathrm{CH}_{4}$ production in $\mathrm{HE}$ rats and tended to increase, but not significantly, $\mathrm{H}_{2}$ and $\mathrm{CH}_{4}$ production in $\mathrm{CV}$ rats (interaction flora $\times$ diet $P<0 \cdot 001)$.

\section{Caecal pH, SCFA and lactic acid concentration}

GF rats were characterized by an approximately neutral caecal $\mathrm{pH}(6 \cdot 8-6.9)$, a low SCFA caecal concentration (only acetate) and no lactic acid, independently of the diet (Table 6).

In all rats fed on the control diet caecal $\mathrm{pH}$ was similar. L-lactic acid concentration was similar in CV and $\mathrm{HE}$ rats but D-lactic acid was threefold lower in $\mathrm{HE}$ rats than in CV rats. SCFA concentration was higher in CV rats than in HE rats and the composition was different: the caecum of $\mathrm{CV}$ rats contained less acetate and more propionate, valerate and the corresponding iso-acids than that of $\mathrm{HE}$ rats.

TOS intake lowered the $\mathrm{pH}$ but this effect was higher in $\mathrm{CV}$ rats than in HE rats (interaction $P<0.001$ ). TOS slightly increased L-lactic acid and decreased D-lactic acid $(3.8-1.5 \mu \mathrm{mol} / \mathrm{g})$ in CV rats; TOS decreased $\mathrm{L}$-lactic acid in HE rats. TOS did not increase SCFA caecal concentration significantly, but it slightly increased butyrate proportion in the caecum of $\mathrm{CV}$ and $\mathrm{HE}$ rats, propionate proportion in $\mathrm{CV}$ rats and proportion of valerate in $\mathrm{HE}$ rats. It significantly decreased isovalerate and isobutyrate in $\mathrm{CV}$ and $\mathrm{HE}$ rats. 
Table 6. Caecal pH, SCFA and lactic acid of germ-free $(G F)$, conventional $(C V)$ and heteroxenic $(H E)$ rats fed on control $(C)$ or trans-galacto-oligosaccharide (TOS) diet*

(Mean values for four rats with their pooled standard errors; error df 18)

\begin{tabular}{|c|c|c|c|c|c|c|c|c|c|c|}
\hline \multirow{2}{*}{$\begin{array}{l}\text { Rats... } \\
\text { Diet... }\end{array}$} & \multicolumn{2}{|c|}{ GF } & \multicolumn{2}{|c|}{$\mathrm{CV}$} & \multicolumn{2}{|c|}{ HE } & \multirow[b]{2}{*}{$\begin{array}{c}\text { Pooled } \\
\text { SEM }\end{array}$} & \multicolumn{3}{|c|}{ Variance analysis } \\
\hline & $\mathrm{C}$ & TOS & $\mathrm{C}$ & TOS & $\mathrm{C}$ & TOS & & Flora & Diet & $\begin{array}{l}\text { Inter- } \\
\text { action }\end{array}$ \\
\hline $\mathrm{pH}$ & $6 \cdot 8^{\mathrm{a}}$ & $6 \cdot 9^{a}$ & $6 \cdot 8^{a}$ & $6 \cdot 2^{c}$ & $6 \cdot 8^{\mathrm{a}}$ & $6 \cdot 6^{b}$ & 0.03 & 0.001 & 0.001 & 0.001 \\
\hline $\begin{array}{l}\text { L-lactic acid } \\
(\mu \mathrm{mol} / \mathrm{g})\end{array}$ & nd & nd & $2 \cdot 1^{\mathrm{a}}$ & $3 \cdot 6^{\mathrm{bc}}$ & $2 \cdot 8^{c}$ & $1.9^{\mathrm{ab}}$ & 0.6 & 0.001 & NS & 0.05 \\
\hline $\begin{array}{c}\text { D-lactic acid } \\
(\mu \mathrm{mol} / \mathrm{g})\end{array}$ & nd & nd & $3 \cdot 8^{b}$ & $1 \cdot 5^{\mathrm{a}}$ & $1 \cdot 8^{\mathrm{ab}}$ & $1 \cdot 3^{b}$ & $0 \cdot 5$ & 0.001 & 0.001 & 0.001 \\
\hline $\mathrm{SCFA}(\mu \mathrm{mol} / \mathrm{g})$ & $0 \cdot 1^{\mathrm{c}}$ & $0 \cdot 1^{\mathrm{c}}$ & $71^{\circ}$ & $83^{a}$ & $32^{\mathrm{b}}$ & $43^{\mathrm{b}}$ & 8 & 0.01 & NS & NS \\
\hline $\mathrm{C} 2 \%$ & 100 & 100 & $64^{c}$ & $60^{c}$ & $72^{\mathrm{b}}$ & $73^{b}$ & 2 & 0.001 & NS & NS \\
\hline $\mathrm{C} 3 \%$ & - & - & $22^{\mathrm{b}}$ & $28^{a}$ & $18^{\mathrm{c}}$ & $15^{\circ}$ & 1 & 0.001 & NS & 0.05 \\
\hline iso-C4\% & - & - & $3^{\mathrm{a}}$ & $1^{\mathrm{a}}$ & $3^{\mathrm{b}}$ & $2^{\mathrm{c}}$ & $0 \cdot 2$ & 0.001 & 0.001 & 0.001 \\
\hline $\mathrm{C} 4 \%$ & - & - & $7^{\mathrm{b}}$ & $8^{\mathrm{a}}$ & $5^{c}$ & $7^{b}$ & 0.2 & 0.001 & 0.01 & NS \\
\hline iso- $\mathrm{C} 5 \%$ & - & - & $2^{a}$ & $\mathrm{l}^{\mathrm{b}}$ & $1^{\mathrm{b}}$ & $1^{b}$ & $0 \cdot 1$ & 0.001 & 0.001 & 0.01 \\
\hline C $5 \%$ & - & - & $2^{\mathrm{a}}$ & $2^{a}$ & $1^{\mathrm{v}}$ & $2^{\mathrm{a}}$ & 0.1 & 0.001 & NS & 0.001 \\
\hline
\end{tabular}

a, b.c.d Mean values within the same horizontal line with different superscript letters were significantly different (Newman-Keuls test): $P<0.05$.

nd, not detected

* For details of diets and procedures, see pp. 904-905

\section{DISCUSSION}

Results for mucin-containing cells are expressed in terms of positive response to PAS, AB 2.5 and HID staining; i.e. related to the presence of neutral mucin, acid mucin (both sialylated and sulphated) and sulphomucins (strictly sulphated mucins) respectively.

It has been shown in pathological studies that there are qualitative and/or quantitative alterations in epithelial mucins of human adenocarcinomas (Filipe, 1979) or colitis (Smith $\&$ Podolsky, 1986). However, no significant correlation was found between faecal mucusdegrading glycosidases and ulcerative colitis and Crohn's disease (Rhodes et al. 1985a,b). The role of colonic mucus and mucosal glycoproteins was reviewed recently (Rhodes, 1989). Some bacterial strains efficiently metabolize mucus as a substrate in vitro (Gibson et al. 1988). Even though our study only concerns nutritional effects, it is of interest to determine whether the diet and/or the bacterial flora may alter mucin composition totally or partially, leading to variations in neutral, acid, and strictly sulphated mucin ratios.

In rats the number of mucus-containing cells varied according to the absence of bacteria and the bacterial status, the anatomical site and the diet composition.

In the caecum of GF rats the number of mucus cells was lower than that in CV rats, as shown previously by Ishikawa et al. $(1986,1989)$. However, little is known about the mucin composition of rats except that the amino acids of mucus in caecal contents of GF rats are different from those of their CV counterparts (Combe et al. 1976). In our experiment the number of AB 2.5-positive cells was lower than those of PAS- and HID-positive cells in GF compared with $\mathrm{CV}$ rats.

The greater extent of staining of the $\mathrm{AB} 2 \cdot 5$-positive subepithelial lumen mucin layer in the caecum and the released mucus still attached to the epithelial goblet cells in the GF distal colon confirm the fact the mucus was not washed away; this finding may be related to the well-known impaired transit time of the intestinal contents in the GF condition.

In the caecum of the GF rat, the small number for AB 2.5-positive cells in the crypts 
(Table 1) and the observation of an increased extent of staining from the subepithelial lumen mucus layer to the intraluminal caecal contents (Table 2) suggested that acid mucin is secreted from goblet cells located in the crypts and may explain this very small number for acid-mucin-containing cells. These observations were similar with or without TOS in the diet.

In the caecum of the $\mathrm{CV}$ rat, despite a greater number of $\mathrm{AB} 2 \cdot 5$-positive cells in the crypts, as compared with the GF rat (Table 1), the extent of staining of the subepithelial lumen mucus layer was weaker than that in GF rats (Table 2), both with or without TOS in the diet. However, intraluminal caecal contents were highly stained. The weaker staining of the subepithelial luminal mucus layer, especially with TOS in the diet, for acid mucin and sulphomucin might be due to the activity of bacteria located in this mucus layer, and the role of bacterial mucin sulphatases could be involved in this effect.

In GF rats the number of mucus-containing cells increased from the caecum to the colon. A similar finding was observed only for acid mucin in CV rats. In the distal colon of both types of rats the proportion of the three types of mucin appeared similar. In the proximal colon acid mucin remained slightly lower in GF rats than in CV rats. On the contrary, recent work with mice reported more acid-mucin-containing cells in the ascending colon of GF compared with specified pathogen-free counterparts (Hill \& Cowley, 1990), suggesting a bacterial specificity for mucin distribution.

TOS ingestion had no effect in the caecum of GF rats but it modified the mucin cell distribution in the colon. The lower number of mucus cells observed here for the three types of mucins in the proximal colon and the greater number in the distal colon may be related to the fact that TOS may act in the large intestine of GF rats by modifying the osmolality of contents. It had been demonstrated by Sakata \& Engelhardt $(1981 a, b)$ using solutions of SCFA of variable osmolalities that the lowest osmolality caused a considerable release of mucins from goblet cells both in the proximal and distal colon, and that the lower the osmolality the larger the mucin release.

In CV rats TOS had no effect in the colon, whereas it decreased the number of acidmucin-containing cells in the caecum. This difference may be due to the presence of a higher SCFA concentration in caecal contents compared with colon contents (Rémésy \& Demigné, 1976).

It was of interest to observe that human bacterial flora could hydrolyse rat mucin, since sugar constituents are similar, despite structural differences reported between rat and human mucins (Allen, 1981). The mucolytic activities obtained were of the same magnitude in $\mathrm{HE}$ and $\mathrm{CV}$ rats fed on the control diet, showing that the human flora can hydrolyse rat mucin.

However, fermentative bacterial metabolism was not similar in $\mathrm{HE}$ and in $\mathrm{CV}$ rats; $\mathrm{CV}$ rats produced more gas and had higher caecal SCFA concentrations than HE rats. Similar to the observations of Debure et al. (1989), the proportion of acetic acid was higher and that of propionic, butyric and valeric acids lower in $\mathrm{HE}$ rats than in $\mathrm{CV}$ rats. Nevertheless these authors observed similar total SCFA concentrations in HE rats and in CV rats. A previous comparison between two groups of rats inoculated with two different human floras from methane and non-methane producers respectively has shown large differences in caecal SCFA concentrations and in L-lactic acid: D-lactic acid values (Andrieux et al. 1991). The differences observed in the present experiment might be due to the specificity of the bacterial microflora, since it has been shown that the human flora inoculated into GF rats keeps its major properties; specified bacterial populations, enzymic activities and fermentative profile (Mallett et al. 1987; Debure et al. 1989; Andrieux et al. 1991).

Despite the non-significant increase in caecal SCFA concentrations, the reduction of caecal $\mathrm{pH}$ in $\mathrm{CV}$ and $\mathrm{HE}$ rats and the modifications of the metabolite profile, especially the 
increase in gas production, confirm TOS fermentation in the large intestine. However, no evident relationship between the mucin-containing cell distribution and the bacterial metabolites studied (gas, SCFA, D- or L-lactate) was shown. In order to elucidate the relationship between mucin distribution and specific mucolytic bacterial activities it would be of interest to study gnotoxenic rats associated with bacteria chosen for their specific mucolytic activities and fed on fermentable carbohydrates.

In conclusion, TOS affected mucus cell distribution in the colon of GF rats. The presence of the flora, conventional or human, abolished this effect.

The authors thank the Yakult Institute, Tokyo, Japan, for providing TOS. They are grateful to Mrs A. Bouroche for the translation of the manuscript into English. The technical assistance of Mrs Michèle Serezat is gratefully acknowledged.

\section{REFERENCES}

Allen, A. (1981). Structure and function of gastrointestinal mucus. In Physiology of the Gastrointestinal Tract, pp. 617-639 [L. R. Johnson, editor]. New York: Raven Press.

Andrieux, C., Lory, S., Dufour-Lescoat, C., de Baynast, R. \& Szylit, O. (1991). Physiological effects of inulin in germ-free rats and in heteroxenic rats inoculated with a human flora. Food Hydrocolloids 5, 49-56.

Andrieux, C. \& Sacquet, E. (1986). Effects of amylomaize starch on mineral metabolism in the adult rat: role of the microflora. Journal of Nutrition 116, 991-998.

Cassidy, M. M., Lightfoot, F. G., Grau, L. E., Story, J. A., Kritchevsky, D. \& Vahouny, G. V. (1981). Effect of chronic intake of dietary fibers on the ultrastructural topography of rat jejunum and colon: a scanning electron microscope study. American Journal of Clinical Nutrition 34, 218-228.

Combe, E., Demarne, Y., Guéguen, L., Ivorec-Szylit, O., Meslin, J. C. \& Sacquet, E. (1976). Some aspects of the relationship between gastrointestinal flora and host nutrition. World Review of Nutrition and Dietetics 24, 1-57.

Debure, A., Colombel, J. F., Flourié, B., Rautureau, M. \& Rambaud, J. C. (1989). Comparaison de l'implantation et de l'activité métabolique d'une flore fécale de rat et d'une flore fécale humaine inoculée chez le rat axénique (Implantation and metabolic activity of rat and human faecal bacterial flora administered to germ-free rats). Gastroentérologie Clinique et Biologique 13, 25-31.

Filipe, I. (1979). Mucins in the human gastrointestinal epithelium: a review. Investigation in Cell Pathology 2 , 195-216.

Gibson, G. R., Cummings, J. H. \& Macfarlane, G. T. (1988). Use of a three-stage continuous culture system to study the effect of mucin on dissimilatory sulfate reduction and methanogenesis by mixed populations of human gut bacteria. Applied and Environmental Microbiology 54, 2750-2755.

Heneghan, J. B. (1979). Enterocyte kinetics, mucosal surface area and mucus in gnotobiotes. In Clinical and Experimental Gnotobiotics. Proceedings of the VI International Symposium on Gnotobiology, pp. 19-27 [T. M. Fliedner, H. Heit, D. Niethammer and H. Pflieger, editors]. Stuttgart: Gustav Fischer Verlag.

Heneghan, J. B., Gordon, H. A. \& Miniats, O. P. (1979). Intestinal mucosal surface area and goblet cells in germfree and conventional piglets. In Clinical and Experimental Gnotobiotics. Proceedings of the VI International Symposium on Gnotobiology, pp. 109-111 [T. M. Fliedner, H. Heit, D. Niethammer and H. Pflieger, editors]. Stuttgart: Gustav Fischer Verlag.

Hill, R. R. \& Cowley, H. M. (1990). The influence of colonizing micro-organisms on development of crypt architecture in the neonatal mouse colon. Acta Anatomica 137, 137-140.

Hoskins, L. C. \& Boulding, E. T. (1981). Mucus degradation in human colon ecosystems. Journal of Clinical Investigation 67, 163-172.

Ishikawa, K., Satoh, Y., Oomori, Y., Yamano, M., Matsuda, M. \& Ono, K. (1989). Influence of conventionalization on cecal wall structure of germfree Wistar rats: quantitative light and qualitative electron microscopic observations. Anatomy and Embryology 180, 191-198.

Ishikawa, K., Satoh, Y., Tanaka, H. \& Ono, K. (1986). Influence of conventionalization on small intestinal mucosa of germfree Wistar rats: quantitative light microscopic observations. Acta Anatomica 128, 296-302.

Ito, M., Deguchi, Y., Miyamori, A., Matsumoto, K., Kikuchi, H., Kobayashi, Y., Yajima, T. \& Kan, T. (1990). Effects of administration of galacto-oligosaccharides on the human fecal microflora, stool weight and abdominal sensation. Microbial Ecology in Health and Disease 3, 285-292.

Le Coz, Y., Morel, M. T., Bousseboua, H., Dufour, C. \& Szylit, O. (1989). Mise au point d'une chambre . respiratoire connectée sur isolateur pour la mesure in vivo des gaz de fermentation chez l'animal gnotoxénique (Development of a respiratory chamber and its connection with an isolator: a method to measure the in vivo production of fermentation gas by gnotobiotic animals). Science et Techniques des Animaux de Laboratoire 14, $35-39$

Loesche, W. J. (1968). Accumulation of endogenous protein in the caecum of the germfree rat. Proceedings of the Society for Experimental Biology and Medicine 129, 380-384. 
McManus, J. F. A. (1946). Histological and histochemical use of periodic acid. Stain Technology 23, 99-108.

Mallett, A. K., Bearne, C. A., Rowland, I. R., Farthing, M. J. G., Cole, C. B. \& Fuller, R. (1987). The use of rats associated with a human faecal flora as a model for studying the effects of diet on the human gut microflora. Journal of Applied Bacteriology 63, 39-45.

Moré, J., Fioramonti, F., Benazet, F. \& Bueno, L. (1987). Histochemical characterization of glycoproteins present in jejunal and colonic goblet cells of pigs on different diets. A biopsy study using chemical methods and peroxidase-labelled lectins. Histochemistry 87, 189-194.

Mowry, R. W. \& Winkler, C. H. (1956). The coloration of acid carbohydrate of bacteria and fungi in the tissue sections with special reference to capsules of Cryptococcus neoformis, Pneumococci and Staphylococci. American Journal of Pathology 32, 628-629.

Rémésy, C.\& Demigné, C. (1976). Partition and absorption of volatile fatty acids in the alimentary canal of the rat. Annales de Recherches Vétérinaires 7, 39-55.

Rhodes, J. M. (1989). Colonic mucus and mucosal glycoproteins: the key to colitis and cancer? Gut 30, 1660-1666.

Rhodes, J. M., Gallimore, R., Elias, E., Allan, R. N. \& Kennedy, J. F. (1985a). Faecal mucus degrading glycosidases in ulcerative colitis and Crohn's disease. Gut 26, 761-765.

Rhodes, J. M., Gallimore, R., Elias, E. \& Kennedy, J. F. (1985b). Faecal sulphatase in health and in inflammatory bowel disease. Gut 26, 466469.

Sakata, T. \& Von Engelhardt, W. (1981 $a$ ). Influence of short-chain fatty acids and osmolality on mucin release in the rat colon. Cell and Tissue Research 219, 371-377.

Sakata, T. \& Von Engelhardt, W. (1981 b). Luminal mucin in the large intestine of mice, rats and guinea pigs. Cell and Tissue Research 219, 629-635.

Salyers, A. A., Vercellotti, J. R., West, S. E. H. \& Wilkins, T. D. (1977). Fermentation of mucus and plant polysaccharides by strains of Bacteroides from the human colon. Applied Environmental Microbiology 33, 319-322.

Schneeman, B. O., Rechter, B. D. \& Jacobs, L. R. (1982). Response to dietary wheat bran in the exocrine pancreas and intestine of rats. Journal of Nutrition 112, 283-286.

Smith, A. C. \& Podolsky, D. K. (1986). Colonic mucin glycoproteins in health and disease. Clinics in Gastroenterology 15, 815-837.

Spicer, S.S. (1965). Diamine methods for differentiating mucosubstances histochemically. Journal of Histochemistry and Cytochemistry 13, 211-231.

Sprinz, H., Kundel, D. W., Dammin, G. J., Horowitz, R. E., Scheiner, H. \& Formal, S. B. (1961). The response of the germfree guinea pig to oral bacterial challenge with Escherichia coli and Shigella flexneri. American Journal of Pathology 39, 681-695.

Staley, T. E., Corley, L. D.\& Jones, E. W. (1970). Early pathogenesis of colitis in neonatal pigs monocontaminated with Escherichia coli. Fine structural changes in the colonic epithelium. American Journal of Digestive Diseases 15, 923-935.

Szylit, O., Dabard, J., Durand, M., Dumay, C., Bensaada, M. \& Raibaud, P. (1988). Production of volatile fatty acids as a result of bacterial interactions in the cecum of gnotobiotic rats and chickens fed a lactose-containing diet. Reproduction, Nutrition, Développement 28, 1455-1464.

Tanaka, R., Takayama, H., Morotomi, M., Kuroschima, T., Ueyama, S., Matsumoto, K., Kuroda, A. \& Mutai, M. (1983). Effects of administration of TOS and Bifidobacterium breve 4006 on the human fecal flora. Bifidobacteria Microflora 2, 17-24.

Vahouny, G. W., Le, T., Satchithanandam, S. \& Cassidy, M. M. (1985). Stimulation of intestinal cytokinetics and mucin turnover in rats fed wheat bran or cellulose. American Journal of Clinical Nutrition 41, 895-900. 